\title{
Reconstruction of Corruption Law Enforcement in the Anti Rasuah Institution "Corruption Eradication Commission (KPK)" (Based on Approach "Berani Jujur Pecat" (Dare Honest Fired)"
}

DOI: https://doi.org/10.47175/rissj.v2i3.231

\section{| Adi Mansar |}

Faculty of Law, Universitas Muhammadiyah Sumatera Utara, Medan, Indonesia

adimansarlubis@gmail.com

\begin{abstract}
Changes to the law are a necessity in accordance with the development of society, whether one law is revised or in the form of reconstruction or deconstruction by changing all existing laws, especially in one state institution that has a special function, for example the Corruption Eradication Commission (KPK) must follow development? What is the Institutional and Personal Position of the KPK after the status transfer to State Civil Apparatus? How effective is the KPK in eradicating corruption after it has been reconstructed? The reconstruction of the KPK institution is expected to bring the KPK to be better, more optimal and remain a supervisory institution for other law enforcement agencies that are able to bring order and legal certainty and justice to the people of Indonesia. The change in the status of KPK employees to State Civil Apparatus is a form of generalizing KPK personnel without making distinctions like so far, so it is feared that there will be no more competition and contestation between the investigative teams who work professionally. The existence of the KPK institution is re-examined with the enactment of Law Number 19 of 2019 concerning the KPK, hopefully the stigma of the superbody institution will remain attached to the KPK will not turn into a super executive institution that works at the request of certain parties and hopefully the KPK will maintain the psychology of the people who hope that the KPK must continue to exist even if fired for doing "HONEST" and the truth. KEYWORDS

protection; business licensing; OSS; PT
\end{abstract}

\section{INTRODUCTION}

Indonesia has been able to carry out reforms through the national student movement well. In 1998, it was marked by the fall of President Soeharto who had ruled for 33 years, followed by BJ. Habibi until 1999.

Since the 1999 General Election, the Reformation era began to be organized in terms of politics, law and security, marked by the separation of Indonesian National Armed Forces (TNI)/ Indonesian National Police (POLRI). Abdurrahman Wahid (GUSDUR) State Gazette of the Republic of Indonesia Number 137 of 2002. The People's Consultative Assembly's decision consists of 6 articles which were stipulated on November 13, 1998 by the Leader (Chairman/Vice Chair) of the People's Consultative Assembly H. Harmoko, Hari Sabarno, Ismail Hasan Materium, Abdul Gafur, Hj. Fatimah Achmad and Poejono Pranyoto. 
As President of the Republic of Indonesia who marked the history of change that was started and continued by Megawati Soekarno Putri, during the leadership of GUSDUR and Megawati Soekarno Putri laws were born like mushrooms in the rainy season, because the amendments to the 1945 Constitution began until the III amendment.

The realization of the amendments to the 1945 Constitution as a basis for the formulation of normative laws, including the KPK Law, which as a norm must be formed because of Law no. 31 of 1999 concerning the Eradication of Criminal Acts of Corruption states that a new institution in the form of the KPK will be formed. ${ }^{1}$ On December 27 , 2002 President Megawati Soekarnoputri ratified the enactment of the KPK Law, marked as promulgated by the Secretary of State on the same day and date and recorded in the State Gazette of 2002 number 137 by the Cabinet Secretary. ${ }^{2}$

The purpose of the establishment of the KPK institution is philosophically inseparable as an effort to minimize corruption which has begun to spread and damage the joints of the state, so that various policies such as the mandate of People's Consultative Assembly's decision No. XI/MPR/1998 concerning the Implementation of a State that is Clean from KKN and juridically it is also related to Law no. 28 of 1999 concerning State Administrators that are Clean and Free from Corruption, Collusion and Nepotism will be created with the existence of a strong anti-corruption institution. ${ }^{3}$

The 19 year old KPK institution has made a lot of positive contributions to eradicating corruption in Indonesia, since 2003-2007 the leadership of the KPK volume I, ${ }^{4}$ in 20072011 the leadership of the KPK volume II whose chairman came from personnel of the Attorney General's Office, ${ }^{5}$ but the period or volume II of the KPK leadership was not completed because there were legal problems faced by the KPK leadership at that time and the KPK leadership was continued by an executor (plt) Tumpak Hatorangan Panggabean and a deputy chairman (plt) Mas Achmad Santosa and the acting vice chairman of Waluyo. The leadership of the KPK volume III 2011-2015 is almost the same as volume II almost all KPK commissioners cannot complete their tenure at the KPK because there are legal problems involving the KPK leadership, ${ }^{6}$ to cover the vacancy in 2005 appointed acting chairman of the KPK, among others: Taufiqurrahman Ruqie, Johan Budi Sapto Pribowo, Indrianto Seno Adji. The KPK leadership volume IV for the 2015-2019 period was able to complete its period until the service period was over, in fact there were KPK leaders reelected for the next period 2019-2023. ${ }^{7}$

The leadership period of the KPK volumes I 2003-2007 and volumes II, III, IV, was a movement to clean the country from the thieves of state money, so that many external problems arose, for example there were cases of lizards and crocodiles, between the KPK

\footnotetext{
${ }^{1}$ See Article 43 of Law no. 31 of 1999 concerning the Eradication of Criminal Acts of Corruption as amended by Law no. 20 of 2001. As the basis for the establishment of the KPK, starting with the issuance of Law no. 30 of 2002 in accordance with the "phrase" No later than two years since the enactment of Law no. 31 of 1999 , a special KPK institution will be established".

${ }^{2}$ State Gazette of the Republic of Indonesia Number 137 of 2002.

${ }^{3}$ The People's Consultative Assembly's decisionconsists of 6 articles which were stipulated on November 13, 1998 by the Chairman (Chairman/Vice Chair) of the The People's Consultative Assembly's decisionH. Harmoko, Hari Sabarno, Ismail Hasan Materium, Abdul Gafur, Hj. Fatimah Achmad and Poejono Pranyoto.

${ }^{4}$ The head of the KPK volume I, Chairman Taufiqurrahman Ruqie, Deputy Chairperson Erry Riyana Hardjapamekas, Tumpak Hatorangan Panggabean, Amein Sunaryadi, Sjahruddin Rasul.

${ }^{5}$ The leadership of the second volume of the KPK, Chairperson Antasari Azhar, Deputy Chairperson, Bibit Samad Rianto, Chandra M Hamzah, Mochamad Jasin, Haryono Umar.

${ }^{6} \mathrm{Head}$ of the third volume of the KPK, Chairman Abraham Samad, Deputy chairman Bambang Widjojanto, Muhammad Busro Muqqodas, Adnan Pandu Praja.

${ }^{7}$ Chairman of the KPK for Volume IV, Chairman Agus Raharjo, Deputy Chairperson Basaria Panjaitan, Alexander Marwata, Saut Situmorang, Laode M. Syarif.
} 
and the POLRI, there were cases of murder for love triangle, between Antasari Azhar and the victim Nasrudin Zulkarnaen, there was a criminalization case of the KPK leader Abraham Samad, Bambang Widjojanto by the POLRI because the Korlantas case emerged and involved state officials, there was a case of weakening the KPK by changing the KPK law, marked by the issuance of Law no. 10 of 2015 concerning the Corruption Eradication Commission. The weakening of the KPK because every wiretapping must have a permit and then there are the KPK supervisors who always get information about who, when and what cases will be tapped, this is for reasons of Human Rights (HAM).

\section{Problems}

1. What is the Institutional and Personal Position of the KPK after the Status Change to State Civil Apparatus?.

2. How effective is the KPK in eradicating corruption after it has been reconstructed?

\section{RESULTS AND DISCUSSION}

\section{KPK Institutional and Personal Position of KPK after Change of Status to State Civil Apparatus?}

Consideration of Law no. 19 of 2019 concerning the second amendment to Law no. 30 of 2002 concerning the Corruption Eradication Commission (KPK) letter b. It reads "that the Police, the Prosecutor's Office, and the KPK as institutions that handle corruption cases need to improve their synergy so that each of them can be efficient and effective in efforts to eradicate corruption based on the principle of equality of authority and protection of human rights.

The preamble above places the keyword in the form of a "phrase" of synergy between fellow investigative agencies, it can be interpreted that all institutions/agencies authorized to investigate have the same functions and duties in terms of eradicating corruption. Placing synergy seems to eliminate the nature of the KPK institution which is ad hoc and superbody and becomes an ordinary state institution whose daily activities have routine activities, even though the KPK is the Corruption Eradication Commission which is primarily a movement to eradicate corruption with all the authorities it has under the law, ${ }^{8}$

The KPK, which was originally designed as a Superbody institution, began to change its powers or special immunity regarding supervision, as evidenced in 2019 there was a Focus group discussion (FGD) organized by the Board of Professors of the Military Law College (STHM) in Jakarta on 12 September 2019 with discussions on the revision of the KPK Law. All state institutions must be supervised and controlled so that they are not arbitrary in acting and making decisions. Furthermore, according to Hendro Priyono, in accordance with the branches of power in Indonesia, the independent institutions are the executive, legislative and judiciary, the existence of the KPK as an institution to eradicate corruption must be included in these institutions. ${ }^{9}$

The Indonesian people have high hopes with the birth of the KPK, because the existing state institutions and are given investigative authority are not able to realize good law enforcement, because there is selective selection of cases and tends to be discriminatory in addition to insinuations between the Police and the Prosecutor's Office in terms of authority. Corruption investigation. The birth of the KPK has become an icon in every effort to eradicate corruption in Indonesia to create a just, prosperous and prosperous

\footnotetext{
${ }^{8}$ Hendro Priyono, Revision of the KPK Law so that there is no Superbody Institution, Republic on 12 September 2019 Thursday, 22.59 WIB,-

${ }^{9}$ Ibid
} 
society. The public believes that the superbody nature of the KPK institution is a big capital for KPK investigators to carry out their duties and authorities, so there are questions from the public why the KPK is seen as a superbody institution, including:

1. Independent and free from the influence of power.

2. The KPK was formed specifically with the aim of increasing the efficiency and effectiveness of efforts to eradicate corruption.

3. In carrying out its duties, the KPK applies the principles of legal certainty, openness, accountability, public interest, and proportionalism.

4. The authority of the KPK exceeds that of conventional law enforcement. ${ }^{10}$

The nature of the superbody of the KPK institution continues with cases that become a priority for handling, especially in terms of the amount of state losses that are a priority for the KPK of at least 1 billion. One of the strengths of the KPK institution is the minimal state financial losses handled by the KPK, except for cases that are caught red-handed. According to Tumpak Hatorangan Panggabean, the former commissioner of the KPK, said that the KPK is a superbody institution that is supervised by the people, so that the superbody nature of the KPK must be maintained, which functions to supervise and in certain circumstances can take over the duties and authorities of other investigators that are being carried out by the Police and the Prosecutor's Office. ${ }^{11}$

In carrying out the corruption eradication program, the KPK is assisted by investigators from the POLRI and the Prosecutor's Office as well as independent KPK investigators who have become KPK employees. Currently, there are 117 KPK investigators under the Directorate of Investigation, all of whom participated in an investigation training program for 5 (five) weeks, with the following materials:

1. Laws and Legislation

2. Investigation

3. Capacity building. ${ }^{12}$

The KPK in 2021 conducted a national insight test (TWK) on 1,349 KPK employees apart from the material that had been completed above, then it was known that 75 of them did not pass based on the Decree (SK) of the KPK leadership Number 652 of 2021 which was signed by the Chairperson of the KPK Komjen Police Firli Buhari.

Table 1. Names of KPK Investigators Who Did Not Pass TWK and were Expelled from the KPK

\section{No Names That Did Not Pass TWK Position}

\begin{tabular}{lll}
\hline 1. & Sujanarko & Director of PJKAKI \\
2. Ambarita Damanik & Task Force of investigator \\
3. Arien Winiasihulp & \\
4. Chandra Susilo & \\
5. Hotman Tambunan & Head of the education and training task force \\
6. Giri Suprapdiono & Director of Anti-Corruption Social Security \\
7. Harun Al-Rasyid & Deputy Chief WP/Senior Investigator \\
8. Iguh Sipurba & Task Force of investigator \\
9. Herry Muryanto & Deputy for bribery corruption
\end{tabular}

10 Arba'a achmadjn Yudho S

\footnotetext{
${ }^{10}$ see also Article 3, Article 4 and Article 6 of the KPK Law.

${ }^{11}$ Tumpak: KPK is a Superbody institution that is supervised by the people, detik.news,October 07, 2011.

${ }^{12}$ Febridiansyah, 2019 KPK spokesman. Kompas. Com on April 23, 2019.
} 
11 Faisal

12 Herbert Nababan

13 Afief Yulian Miftach

14 Budi Agung Nugroho

15 Novel Baswedan

16 Novarizal

17 Budi Sokmo Wibowo

18 Sugeng Basuki

19 Agtaria Adriana

20 Aulia Postoera

21 M. Praswad Nugraha

22 March Falentino

23 Marina Febriana

24 Yudi Purnomo Harahap

25 Yulia Anastasia Fu'ada

26 Andre Dedy Nainggolan

27 Ahmad Fajar

28 Airien Marttanti Koesniar

29 Juliandi Tigor Simanjuntak

30 Nurul Huda Suparman

31 Rasamala Aritonang

32 Andi Abdul Rachman

33 Nanang Priyono

34 Qurotul Aini Mahmudah

35 Hasan

36 Rizki Bayhaqi

37 Rizka Anungnata

38 Candra Septina

39 Waldy Gagantika

40 Abdan Syakuro

41 Ronald Paul

42 Panji Prianggoro

43 Damas Widyatmoko

44 Rahmat Reza MAsri

45 Benydictus Siumlala Martin S

46 Adi Prasetyo

47 Ita Khoiriyah

48 Tri Artining Putri

49 Christie Afriani
Former Chairman of WP

Investigator

Task Force of investigator

Task Force of investigator

Task Force of investigator

Investigator

Investigator

Investigator

Investigator

Investigator

Head of WP KPK/Investigator

Task Force of investigator

Investigator

Head of the Asset Tracking task force

Task Force of investigator

Investigator

The KPK has inaugurated 1,271 employees to become State Civil Apparatus (ASN) online with representatives of 53 people including structural officials on June 1, 2021 to coincide with the birthday of Pancasila. As many as 51 people were dismissed because they did not pass the National Insight Test (TWK) and 24 people were deemed worthy of participating in national insight education and then appointed as ASN. 
According to Taufik Basari, a member of the House of Representatives Commission III from the Nasdem Party, it is not appropriate to dismiss 51 KPK employees even though they are not willing to become ASN, a middle way must be found even though all KPK employees will be transferred to ASN status because of the Law and Government Regulation (PP) Number 41 of 2020 concerning the Transfer of KPK Employees to ASN which was signed by the President on July 24, 2020. To follow up on Law No. 19 of 2019 and PP No. 41 of 2020 the KPK leadership has issued Commission Regulation (PERKOM) Number 1 of 2021 concerning Procedures for Transferring Employee Status to State Civil Apparatus (ASN) which divides there are 3 (three) types of KPK employees, including:

1. Permanent Employee of the KPK

2. Non-Permanent KPK Employees

3. Government Employees with Employment Agreement. ${ }^{13}$

The transfer of the status of KPK employees to ASN even though the mandate of the law is an effort to uniform the status of KPK employees and is under one general body, namely the State Civil Service Agency (BKN) in terms of duties and responsibilities that can be contested by superiors if they do not want to follow the request of superiors. . In the author's opinion, it is very detrimental to the enforcement of corruption laws in this country and affects the morale of eradicating corruption.

Parameters that the author can convey have a personal effect, including:

1. The independence and professional work of KPK employees after becoming ASN is lost, because Corruption itself involves a lot of ASN among the government,-

2. Competition between fellow work teams in the midst of corruption eradication work will be lower, because the position depends on whether or not the leader likes it, not based on achievement and experience,-

3. There is a polarization between fellow ASN whose backgrounds are different from the initial agency, because the line of coordination with other institutions depends on the liaison personnel, not the institution's policies,-

4. The KPK will become a shelter for investigators who move from other institutions with temporary status or work agreements, this is vulnerable to corruption by the KPK investigators who blackmail the public, see the case of Mayor Tj. Hall,-

5. Worried about waking up in the community with one view, if the KPK is similar to investigators from the prosecutor's office and the police, it is better to just dissolve it, because it is weak and tends to be corrupt.

From the author's analysis based on empirical facts during the 19 years of the establishment of the KPK, people believe in the KPK because the status of KPK employees is not generalized like one particular department, because the strength of the KPK with the support of many participating State institutions has brought the best personnel to serve at the KPK.

The effective is the KPK in eradicating corruption after it has been reconstructed? The first philosophy is the revision of the KPK Law Number 19 of 2019 which reaches Article 70 for synergy between fellow corruption law enforcement agencies, the meaning of synergy in the contestation process between corruption law enforcement agencies will be lost and the supervisory function of the KPK fades because the highest level of cooperation is between institutions. The meaning of cooperation will eliminate the meaning of super body and eliminate the specialization of the KPK as an institution that investigates large amounts of corruption.

\footnotetext{
${ }^{13}$ See also Commission Regulation (PERKOM) No. 1 Year 2021.
} 
After the reconstruction of the Corruption Eradication Commission Law which required it to occur, the KPK as a unit of government agency apparatus together with the Police and/or the Prosecutor's Office carried out integrated and structured efforts in preventing and eradicating corruption. Then form a strong network and enforce existing institutions as conducive partners so that the prevention and eradication of corruption can be carried out more effectively, efficiently, coordinated, and in accordance with the general provisions stipulated in the legislation. Reducing the imbalance of relations between law enforcement institutions in preventing and eradicating corruption, by not monopolizing and disputing the duties and authorities of investigation, investigation, and prosecution as well as cooperating in supervising and monitoring existing institutions in a joint effort to prevent and eradicate corruption.

The reconstruction of the KPK was carried out in line with the Constitutional Court's decision Number 36/PUU-XV/2017 which stated that the KPK was a branch of government power. However, in its development, according to the author, the performance of the KPK will be increasingly ineffective because the entire performance of the KPK will be forced in accordance with the provisions of the Criminal Procedure Code without a solid legal politics and is getting worse political institutions to influence them. There are several factors that tend to influence and even interfere with the performance of the KPK in the future after 1,271 new KPK employees were appointed by the Chair of the KPK, including:

\section{Political Developments.}

Policies that are formed and born in a government can be seen from government programs that are in power, tools for smoothing power often use law by forming legislation or revising existing ones. The revision of one law tends to follow the background of the thoughts of the leadership of a cabinet and leads to the platform of the party that carries the government.

The revision of Law Number 30 of 2002 has been carried out twice since President Jokowi's administration was marked by the birth of PERPU Number 1 of 2015 which was stipulated based on Law no. 10 of 2015 concerning the KPK which was later revised based on Law no. 19 of 2019 which is the second revision of the KPK law,-

Since its establishment until now, the KPK has changed its leadership 5 (five) times as volumes 1 to volume $\mathrm{V}$ with different government leaders (the president changed 3 times), during the period of President Megawati and President Soesilo Bambang Yoedoyono (SBY). there are changes and revisions at all, politically the law can be studied as follows:

a) The development of legal politics in the era of the President (megawati and SBY) responded to grassroots requests for the dangers of corruption, both for political parties, legislative, judicial and executive institutions including the TNI/Polri,-

b) The existence of the KPK institution in the 2003-2014 era was the heyday of the KPK in shaping the history of this country in law enforcement of corruption, because law enforcement indiscriminately, the general chairman of the party, members of the DPR, Ministers, Prosecutors, Police, TNI, Supreme Court Justices, and other important officials including the chairman of the Republic of Indonesia,-

c) KPK employees becoming ASN since June 1, 2021 is the lowest point of the decline in corruption law enforcement on all lines, many important state institutions will not be able to dismantle their corruption crimes because investigators bearing the ASN symbol will not be able to enter as long as there is no order from the President as the highest leader. There are questions that arise in the midst of the reconstruction of KPK employees, are conventional law enforcement agencies 
believed to have integrity and corruption does not exist in these state institutions/agencies? The answer to the above question is that due to the reconstruction of KPK employees into ASN, the KPK is institutionally weak and deliberately weakened. There are other efforts that have been established by each law enforcement agency to not interfere with the KPK in every corruption issue in their respective institutionsvby establishing a saber extortion agency/field that will carry out legal proceedings for each individual investigator and all parties involved. Since the establishment of the Corruption Eradication Commission, many cases involving generals have been investigated, such as in 2006, the case of the BNI burglary by Maria Pauline Lumowa and Adrian Waworuntu that linked the names of former Police Chief of Criminal Investigation Unit Komjen Pol Purnawirawan Suyitno Landung and Brigadier General Retired Police Samuel Ismoko. In 2011 the case that attracted public attention was the Gayus Tambunan tax case involving big names such as Inspector General of Police Raja Erisman and Brigadier General Edmon Ilyas, former Director II of the Bareskrim Economy of the Police. SIM Simulator case in 2012 involving former Head of Traffic Police Inspector General Djoko Susilo and Brigadier General Didik Purnomo. In 2020 there was Djoko Candra who dragged the police officers such as Inspector General Pol Napoleon Bonaparte et al who really broke the hearts of the people because it was carried out by people who had been considered to have high integrity. The title of the article on corruption cases is increasing in all professions 15 involving the TNI Brigadier General Teddy Hernayadi, the First Marshal of the TNI FA in the Helicopter Procurement case and TNI Admiral Bambang Udoyo regarding the project to procure satellite monitoring at the Maritime Security Agency (BAKAMLA).

d) Corruption has not subsided, but the KPK has been reconstructed based on general constitutional principles that want to position the KPK institution under the executive so that it can be controlled by political power, budget and a superiorsubordinate system.

According to Philip Nonet, the atmosphere of reduced belief in the law is evident in recent writings, criticism of the law has always been aimed at the inadequacy of law as a tool for change and as a tool for achieving substantive justice. discussion of a crisis of legitimacy, a conservative red flag of the erosion of authority. At present, the KPK's authority is being minimized and politically eroded by means of a revised KPK law and eventually all KPK employees are transferred to status.

The misuse of legal activism further adds to the breakdown of "law and order" and the corruption of the legal order, which we worry about legal institutions being polluted from within, liberal legalization (ASN), the rule of law being a hidden enemy.

\section{Community Psychology}

Development (development) is one of the many confusing thoughts in social science theory, it has been a prolonged critique even since the heyday of evolutionism in the 19th century. According to Roscoe Pound is one of those who argue that it is appropriate to think about the stages of development law in a system that has reached the stage of maturity.18 The author agrees with Phlip Nonet who explains that the theory of development is an excessive intellectual endeavor, but in perspective the basis of the theory of development is something valuable and even unavoidable.

Many people are apathetic, including writers, in terms of the existence of the KPK institution in the future, instead of strengthening the authority of the KPK, the fact is that it brings the KPK institution to be increasingly aligned with existing conventional law 
enforcement agencies and so far the people's thinking of the institution is not optimal so that the KPK is needed. Public doubts about the weakening of the KPK institution because several cases of KPK leaders were involved and ethically very inappropriate, for example KPK Commissioner Lili Pintauli Siregar communicated with the OTT Corruption TSK Mayor Tj. Balai by giving directions contacted a lawyer with the initials "A" to take care of the case involving Mayor Tj. The hall. So far, the KPK has been supervised by the public, but soon the KPK will be supervised by the executive as the direct superior of the ASN and the involvement of the community will be getting smaller, just like Ministries and Departments which tend to be closed.

\section{The Future of Corruption Eradication (KPK)}

We must continue to promote the eradication of corruption as legal politics to save the country from economic and social downturn, so that the anti-corruption movement and anti-corruption education must be encouraged from an early age. Campus institutions must be at the forefront to realize anti-corruption education, State officials should not waste their bodies blaming educational institutions like Prof. Dr. Mahfud MD, who stated that corruption is increasingly widespread, must be responsible for campuses, is an early warning that the nation's generation must be prepared with anti-corruption capital.

Indonesia's corruption perception index is at 102 out of 180 countries, very bad with the concept of a rule of law that we are proud of. If Indonesia's corruption perception index is in the top 50 in the world, maybe a corruption eradication institution such as the KPK is no longer needed in the future, on the other hand, if Indonesia's corruption perception rate is still above the world's 50, then the KPK should not be bonsai. or do not be weakened let alone disbanded.

\section{CONCLUSION}

The reconstruction of the KPK institution is expected to bring the KPK to be better, more optimal and remain a supervisory institution for other law enforcement agencies that are able to bring order and legal certainty and justice to the people of Indonesia. The change in the status of KPK employees to ASN is a form of generalizing KPK personnel without making distinctions like so far, so it is feared that there will be no more competition and contestation between the investigative teams who work professionally.

The existence of the KPK institution is re-examined with the enactment of Law Number 19 of 2019 concerning the KPK, hopefully the stigma of the superbody institution will remain attached to the KPK will not turn into a super executive institution that works at the request of certain parties and hopefully the KPK will maintain the psychology of the people who hope that the KPK must continue to exist even if fired for doing "HONEST" and the truth.

\section{Suggestions and Recommendations}

The KPK as an ad hoc state institution should not be confused with other law enforcement agencies, with political institutions that have broad powers, so that the KPK remains a sexy institution whose performance is expected to bring improvements in the legal aspect of corruption.

The institutional reconstruction of the KPK and the change of employee status to ASN are expected to be reviewed as soon as possible because they are believed to be ineffective. 


\section{REFERENCES}

Brilio.Net. (2017). Corruption has penetrated all professions, some generals in the TNI/Polri have been dragged into the vortex of this extraordinary crime case. Accessed on 2 June 2021 at 07.29 WIB

Febridiansyah. (2019). KPK spokesperson. Kompas. Com on April 23, 2019.

Hendro Priyono. (2019). Revision of the KPK Law so that there is no Superbody Institution, Republic on September 122019 Thursday, 22.59 WIB,-

The People's Consultative Assembly's decision consists of 6 articles which were stipulated on November 13, 1998 by the Chairman (Chairman/Vice Chair) of the MPR RI H. Harmoko, Hari Sabarno, Ismail Hasan Materium, Abdul Gafur, Hj. Fatimah Achmad and Poejono Pranyoto.

Philippe Nonet and Philip Selsnick. (2003). Responsive Law, choice of transition period, FF Foundation and HuMa, Jakarta 2003.

Chairman of the KPK volume I, Chairman Taufiqurrahman Ruqie, Deputy Chairman Erry Riyana Hardjapamekas, Tumpak Hatorangan Panggabean, Amein Sunaryadi, Sjahruddin Rasul.

Chairman of the KPK volume II, Chairman Antasari Azhar, Deputy Chairman, Bibit Samad Rianto, ChandraM Hamzah, Mochamad Jasin, Haryono Umar.

Chairman of the KPK volume III, Chairman Abraham Samad, Deputy chairman Bambang Widjojanto,Muhammad Busro Muqqodas, Adnan Pandu Praja.

Chairman of the KPK volume IV, Chairman Agus Raharjo, Deputy Chairman Basaria Panjaitan, AlexanderMarwata, Saut Situmorang, Laode M. Syarif.

Tumpak (2011). KPK lembaga Superbody yang diawasi rakyat, detik.news, accessed Jum'at October 72011.

\section{Law}

Law Number 30 of 2002 concerning the KPK

Law Number 10 of 2015 concerning the KPK

Law Number 19 of 2019 concerning the KPK

PP number 41 of 2020 concerning the KPK

PERKOM No. 1 of 2021 concerning Transfer of KPK employee status 